\title{
PRODUCTION OF BIOETHANOL FROM GROUNDNUT (ARACHIS HYPOGEAE L.) PEELS AND SHELLS
}

\author{
Adejumobi, Iyabode Bright \\ Department of Chemistry, School of Sciences, Federal \\ University of Technology, \\ P.M.B.704. Akure, Nigeria
}

\begin{abstract}
This research investigated the feasibility of groundnuts shells and peels for bio ethanol production. Proximate and fiber composition analysis conducted on the samples were also reported. Fourier Transform-Infrared Ray (FTIR), Refractometer and Scanning Electron Microscopy (SEM) were used to perform analytical investigation on the peels and shells to determine the functional groups and the surface morphology of the samples respectively. The chemical composition of peels and shells were: moisture content of $6.00 \pm 0.09$ and 6.50 \pm 0.10 , ash content of $2.72 \pm 0.09$ and $8.00 \pm 0.11$, lignin of $27.00 \pm 0.28$ and $28.00 \pm 0.50$, hemicellulose of $29.00 \pm 0.76$ and $46.00 \pm 0.01$ and $\alpha$-cellulose of $37.00 \pm 0.58$ and $34.00 \pm 0.28$ respectively. The optimum acid concentration $\left(\mathrm{H}_{2} \mathrm{SO}_{4}\right)$ used for the hydrolysis were $(4 \%$ and $6 \%$ w/v respectively), the best reaction time and temperature were noted at $\left(60 \mathrm{~min}, 100{ }^{\circ} \mathrm{C}\right)$ for peels and $\left(90 \mathrm{~min}, 120{ }^{\circ} \mathrm{C}\right)$ for shells. About $7.89 \%$ and $3.94 \%$ of ethanol were recovered from $100 \mathrm{~g}$ of peels and shells respectively and the FT-IR spectral proved that the bio-liquid obtained from the samples was bioethanol. The SEM for pre-hydrolyzed biomass shows a well-organized and smooth surfaced structure while the post hydrolyzed biomass showed a ruptured surface that revealed effective hydrolysis during liquefaction process. This study showed that the biomass samples are promising feedstock for bio-refining process. Keywords: Groundnut peels, shells, lignin, fermentation, bioethanol.
\end{abstract}

\section{INTRODUCTION:}

The Nigerian environment is highly polluted with enormous amounts of waste such as Agricultural waste, food waste, industrial waste, and animal waste, and these are a major problem in the country [1]. If properly processed and utilize, it can be a potential source of biomass energy in Nigeria [2]. It is estimated that approximately, Nigeria generates 74,428.85 tons of municipal waste daily (or approximately $27,166,530.25$ tons annually) which has a potential biogas generation of 2.04 million $\mathrm{m}^{3}$ every day [3]. Groundnuts are species of legumes. Residues from groundnut pods are called

\author{
Ogunsuyi, Helen Olayinka \\ Department of Chemistry, School of Sciences, Federal \\ University of Technology, \\ P.M.B.704. Akure, Nigeria
}

SHELL and the residue from the roasted nut is called PEELS. The production of peanuts according to the Food and Agriculture Organization (FAO) statistical yearbook in 2013 was $43,982,066$ t, produced in $27,660,802$ hectares [4]. Peanuts are grown mainly in Asia, with a global production rate of $65.3 \%$, followed by Africa with $26.2 \%$, the Americas with 8.4\%, and Oceania with $0.1 \%$.[4].

Only small part of the groundnut shell is used as compost and animal feed. Lately, groundnut shell has been used as a feedstock in oil production. In recent years (2018) the World has been experiencing a tremendous increase in the search for alternative energy sources to replace the conventional fossil fuels due to the finite nature of crude oil and other fossil fuels which must increase by $60 \%$ in 2050 [5]. One of the most attractive alternatives (fossil fuels) is bio-ethanol (alcohol) produced from agricultural crops and residue [6]. The production of ethanol from lignocellulosic wastes is dependent both on the availability in large quantities at low cost. Cellulose is the most abundant biopolymer in the world [7]. Cellulose is found in a wide range of species and present along with hemicelluloses, lignin, pectin, wax and resins [8]. It can be obtained from numerous resources, such as wood, eucalyptus, sisal, cotton, coconut fibers, and non-plant sources, including forms produced by bacteria and found in tunicates. The structure of cellulose is organized into fibrils, which are surrounded by a matrix of lignin, extractive inorganics and hemicellulose [9].

This makes renewable resource an attractive feedstock for the production of motor fuel alcohol [1012].Biomass conversion to bio fuels involves two processes which are thermochemical and biochemical processes. In this study, biochemical conversion was used in production of fermentable sugars and their conversion into liquid fuels ( ethanol, butanol) or gaseous compounds (methane) by use of specific microbial population [13] There are three methods of extracting sugars from biomass, which are concentrated acid hydrolysis, dilute acid hydrolysis and fermentation. Hydrolysis process is the breaking down of the cellulosic part of the biomass into sugar solutions that can then be fermented into ethanol, and yeast is added to the solution. The ethanol, 


\section{International Journal of Engineering Applied Sciences and Technology, 2020 \\ Vol. 4, Issue 11, ISSN No. 2455-2143, Pages 38-44 \\ Published Online March 2020 in IJEAST (http://www.ijeast.com)}

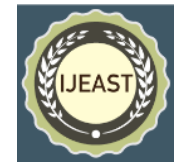

which is produced from the fermentation process, still contains a significant quantity of water, which must be removed. This is achieved by using the fractional distillation process. The distillation process works by boiling the water and ethanol mixture. Since ethanol has a lower boiling point $\left(78.3^{\circ} \mathrm{C}\right)$ compared to that of water $\left(100{ }^{\circ} \mathrm{C}\right)$, the ethanol vaporizes before water, which then condensed and recovered as distillates as described by Ogunsuyi and Badiru [14]. Bioethanol is far better than the conventional fuels. By encouraging bioethanol use, the rural economy would receive a boost from growing necessary crops. Bioethanol is biodegradable and far less toxic than fossil fuels. This study investigated the viability of the biomass as feedstock for the production of bio-ethanol as an alternative fuel to conventional fossil fuel.

\section{MATERIALS AND METHODS}

Sample collection and preparation

Groundnut (Arachis hypogeae L.) peels and shells were collected from a nearby market (Plates $1 \mathrm{a}$ and $1 \mathrm{~b}$ ). Groundnut shells and peels were cleaned and air dried at room temperature for 3 days which led to the removal of dust and sand from the samples. Then, the materials were ground into particle sizes between 1 and $2 \mathrm{~mm}$ using a milling machine. Plate 1a: Groundnut peels

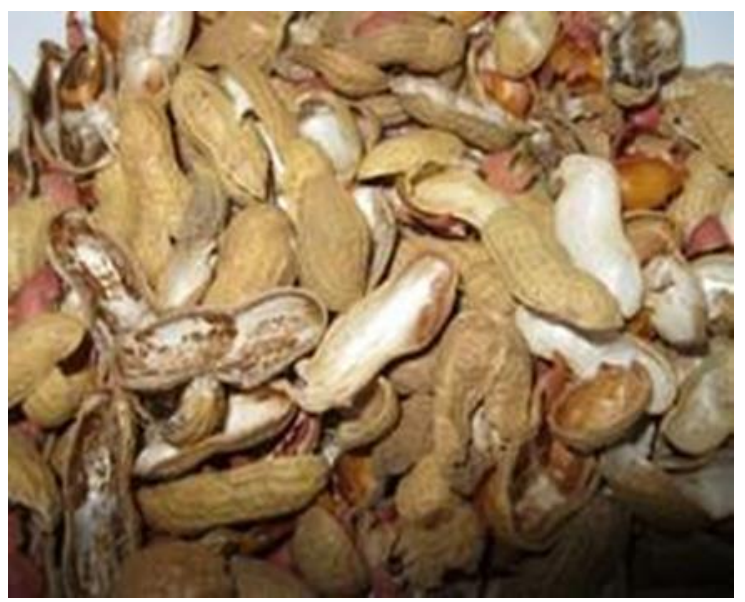

Plate 1b: Groundnut shells

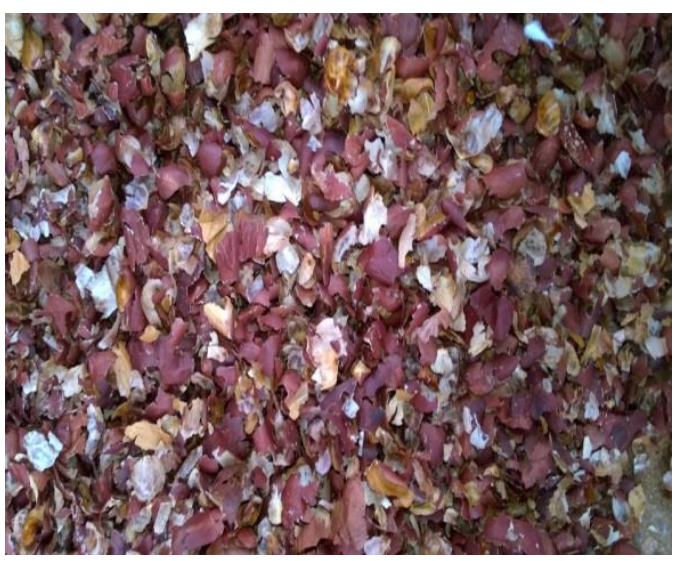

Acid Hydrolysis of Peels and Shells

The Groundnut shells and peels were subjected to acid hydrolysis using $\mathrm{H}_{2} \mathrm{SO}_{4}$ of various concentrations $(2 \%, 4 \%$, $6 \%, 8 \%$, and $10 \%) \mathrm{w} / \mathrm{v}$. The hydrolysis was performed at varying reaction time between $30 \mathrm{~min}$ and $120 \mathrm{~min}$ ) and temperature of $60^{\circ} \mathrm{C}$ and $120^{\circ} \mathrm{C}$.

Fermentation Medium: The hydrolysate was allowed to cool, then filtered to remove the residue and the sugar level was checked using Refractometer. The hydrolysate was neutralized using $2 \mathrm{M} \mathrm{NaOH}$ and adjusted to a $\mathrm{pH}$ of 5.5 using $\mathrm{pH}$ meter.

\section{Process of fermentation}

The yeast used was sacchromyces cerevisiae (20 g) and was activated by using warm water to dissolve it with constant shaking, it was then added to the hydrolysed biomass to ferment for 5 days, thereafter subjected to distillation (ethanol boils at $78^{\circ} \mathrm{C}$ ) and further redistilled with calcium oxide to get purified bio ethanol by using distillation setup consisting of Liebig condenser and fractionating column. The method adopt for the determination of the refractive index was as described by Josly [15], using a refractometer

\section{Extractive Determination}

The biomass was extracted according to TAPP1 T222 standard [16]. About $3 \mathrm{~g}$ of the groundnut peels and shell were weighed inside a filter paper and wrapped with a thread, then placed in the extraction thimble of soxhlet extraction. The boiling flask contained 1:2 ethanol (95\%) and toluene which was extracted for $8 \mathrm{~h}$ and the extraction was distilled to near dryness before evaporation on a heating mantle until the solution was completely evaporated. The flasks were oven dried at $105{ }^{\circ} \mathrm{C}$. The outcome was placed in a desiccator and weighed repeatedly until a constant weight was obtained. The experiment was done in triplicate and the following formulas were used to obtain the extractives in equation 2.1.

$\%$ Extractive $=\frac{W a-W b}{W a} \times 100$

Where $\mathrm{Wa}=$ weight of initial dried samples. $\mathrm{W}_{\mathrm{b}}=$ weight of final dried samples

\section{Determination of Lignin Content}

Lignin, expressed as Klason lignin was estimated directly [17] as follows:

About $1 \mathrm{~g}$ of the extracted sample was put in a $100 \mathrm{ml}$ beaker and then treated with $15 \mathrm{ml}$ of $72 \% \mathrm{H}_{2} \mathrm{SO}_{4}$, added to the sample drop by drop with constant stirring by a stirrer. After complete breakdown, the reaction was allowed to stand and the beaker was covered kept in water bath at $20^{\circ} \mathrm{C}$ for 2 hours, the content was diluted with a volume of $575 \mathrm{ml}$ of distill water, It was then transferred to a 1 liter round bottom flask then heated for 4 hours and left over night at room temperature. The lignin was filtered on an ash less filter paper 


\section{International Journal of Engineering Applied Sciences and Technology, 2020 \\ Vol. 4, Issue 11, ISSN No. 2455-2143, Pages 38-44 \\ Published Online March 2020 in IJEAST (http://www.ijeast.com)}

and washed with hot water and dried at constant weight of $105^{\circ} \mathrm{C}$ in oven. The lignin was calculated according equation 2.2

Lignin $(\%)=\frac{\text { final } \text { Weight }}{\text { initial } \text { Weight }} \times 100 \quad \mathbf{2 . 2}$

Holocellulose estimation

Holocellulose, the total carbohydrate fraction (cellulose and hemicellulose) of the raw material was estimated [18] as follows:

About $1 \mathrm{~g}$ extractive (which was extracted with ethanol toluene mixture $1: 2$ for $8 \mathrm{~h}$ )

was suspended in $150 \mathrm{ml}$ of $1 \mathrm{M}$ sodium acetate and boils for 5 $\mathrm{h}$ at $75^{\circ} \mathrm{C}$ and the solution was stirred mechanically then, 10 drops of glacial acetic acid and at every $1 \mathrm{~h}(4 \mathrm{mls}) 1.5 \mathrm{~g}$ sodium chlorite were added for $4 \mathrm{~h}$ and the reaction has been allowed to proceed under vigorous stirring. The solution was then cooled, filtered and washed with distilled water until free of acid, then with acetone and left to dry at room temperature. The holocellulose was then calculated according to equation 2.3 .

Holocellulose $=\frac{W a-W b}{W a} \times 100$

Wa $=$ Final weight of the dried sample

$\mathrm{Wb}=$ Initial weight of sample

Alpha cellulose content

About 1g of holocellulose sample which does not dissolve in $17.5 \%$ sodium hydroxide solution was added into a $250 \mathrm{ml}$ beaker was left to rise for $3 \min [19]$. The beaker was then covered and left for $35 \mathrm{~min}$ at $20^{\circ} \mathrm{C}$. Distilled water $(100 \mathrm{ml})$ was then added and the material was quickly filtered under suction using a funnel. The filtrate was then poured on the paste twice before washing with distilled water. After washing with distilled water till neutrality $100 \mathrm{ml}$ of $10 \%$ acetic acid was added drop wise followed by distilled water. The temperature was kept constant at $20^{\circ} \mathrm{C}$ during the whole experiment. The alpha cellulose was then calculated (in equation 2.4) after drying at $105{ }^{\circ} \mathrm{C}$ to constant weight.

Alpha cellulose $(\%)=\frac{\text { final weight of oven dried sample }}{\text { intial weight of sample }} \times 100$ 2.4

Hemicellulose Determination

The hemicellulose was determined by difference between holocellulose and $\boldsymbol{\alpha}$-cellulose contents as shown in equation 2.5

Hemicellulose $(\%)=$ Yield of Holocellulose $(\%)-$ Alpha cellulose $(\%)$

\section{RESULTS AND DISCUSSION}

Chemical Composition of Groundnut Biomass

Table 1 shows the amount of moisture in the biomass which was $(6.00 \pm 0.09,6.50 \pm 0.10)$ for peels and shells respectively. The moisture content found in the shells was $5.79 \%$ as reported by Miguel [20]. The ash content of the groundnut peels and shells were $2.72 \pm 0.09,8.00 \pm 0.01$ respectively which were relatively higher compared to Annika [21].

The extractives for shells were $\left(25.50^{\mathrm{d}} \pm 0.70\right)$ and peels $\left(37.95^{\mathrm{c}} \pm 0.05\right)$ were compared. The lignin contents were $27.00 \pm 0.28$ for peels and $28.00 \pm 0.50$ for shells which is relatively low and good for the production of bio ethanol, the hemicellulose were $29.00 \pm 0.76$ for peels and $46.00 \pm 0.01$ for shells. The $\boldsymbol{\alpha}$-Cellulose for peels and shell were $37.00 \pm 0.58$, $34.00 \pm 0.28$ respectively.

Monomeric Sugar Content of the Groundnut Peels and Shells after Hydrolysis and Yeast Assay

The percentage yield of ethanol gotten from groundnut peels and shells were $(31.56 \%, 52.30 \%)$ respectively which was similar to $(0.5 \mathrm{mg} / \mathrm{ml}$ on Day 4.)[22]. Also after purification (with $\mathrm{CaO}$ ), the crude ethanol yield drastically reduced to $7.89 \%$ of peels and $3.94 \%$ of shells. The results showed that the biomass contained a level of fermentable sugar which indicated alcoholic content of bioethanol liquor and that they are promising source of ethanol production.

Results of Peels and Shells Brix Level against Acid Concentration $\left(\mathrm{H}_{2} \mathrm{SO}_{4}\right)$ with temperatures $60{ }^{\circ} \mathrm{C}, 80{ }^{\circ} \mathrm{C}$ and $120{ }^{\circ} \mathrm{C}$

Figure 1 shows the effect of varying acid concentration on brix level in the hydrolysate. The result showed direct proportional increase of the acid concentration with brix. The trend continued and the optimum contact was not obtained at $30 \mathrm{~min}$ until the experiment proceeded to a higher time above $30 \mathrm{~min}$. Figure 2 shows best hydrolysis at $4 \%$ acid, at a time from $60 \mathrm{~min}$ and above the optimum contact was attained at $60 \mathrm{~min}$ for peels and 90min for shell. This implies that quantitative recovery of monomeric sugar is not achievable at lower contact time for groundnut biomass. Figure 3 shows the optimum temperature at $120^{\circ} \mathrm{C}$. The optimum sugar level for shell was attained at $6 \% \mathrm{w} / \mathrm{v}$ of acid concentration.

Properties of the derived bio ethanol

The refractive index for peels and shells were 1.348 and 1.350 respectively and the molecular weight is 46.7 with structural formula of $\mathrm{C}_{2} \mathrm{H}_{5} \mathrm{OH}$. The derived bioethanol boils at $78{ }^{\circ} \mathrm{C}$.

Characterization of Derived Bio ethanol of Groundnut Peels and Shells with FTIR

Figures (4 and 5) were the spectral for FTIR which show the functional groups. Figure 4 shows the spectrum of groundnut peels shows absorption in the following regions: $3426.00 \mathrm{~cm}^{-1}$ $\mathrm{O}-\mathrm{H}$ stretch of alcohol, $1638.70 \mathrm{~cm}^{-1} \mathrm{C}-\mathrm{H}$ stretch of alkane 
and $1042.25 \mathrm{~cm}^{-1} \mathrm{C}-\mathrm{O}$ stretch of alcohol Figure 5 shows the spectrum of groundnut shells shows absorption in the following regions: $3427.00 \mathrm{~cm}^{-1} \mathrm{O}-\mathrm{H}$ stretch of alcohol, $1640.51 \mathrm{~cm}^{-1} \mathrm{C}-\mathrm{H}$ stretch of alkane and $1056.06 \mathrm{~cm}^{-1} \mathrm{C}-\mathrm{O}$ stretch of alcohol. In these spectra, the compound identified proved that samples are bioethanol produced.

Scanning Electron Microscopy

Plate $2 \mathrm{a}, 2 \mathrm{~b}$ and $3 \mathrm{a}, 3 \mathrm{~b}$ shows the scanning electron microscope of Pre and Post hydrolysed groundnut biomass. SEM analysis was carried out on Pre and Post hydrolysed groundnut shells. Plate $2 \mathrm{a}$ and $3 \mathrm{a}$ showed a smooth surface and a compacts structure that is well organized while plate $2 \mathrm{~b}$ and $3 b$ showed a ruptured surface which means it was effective because it had opened the pore space.

Percentage yield of bio ethanol

Weight of biomass $=100 \mathrm{~g}$, weight of derived bio ethanol $=31.56 \mathrm{~g}$

$=\frac{31.56}{100} \times 100=31.56 \%$

Bio ethanol yield after purification $=7.89 \%$

For shells: weight of derived bio ethanol $=52.3 \mathrm{~g}$

$\frac{52.3}{100} \times 100=52.3 \%$

Bio ethanol yield after purification $=3.94 \%$

Table 1: Proximate and Fiber Composition of Groundnut Biomass

\begin{tabular}{|c|c|c|c|}
\hline $\begin{array}{l}\text { Serial } \\
\text { number }\end{array}$ & $\begin{array}{l}\text { Fiber } \\
\text { components }\end{array}$ & Peels (\%) & Shells (\%) \\
\hline 1 & Moisture & $6.50^{\mathrm{a}} \pm 0.10$ & $6.50^{\mathrm{b}} \pm 0.01$ \\
\hline 2 & Ash & $2.72^{\mathrm{a}} \pm 0.09$ & $8.00^{\mathrm{a}} \pm 0.01$ \\
\hline 3 & Extractive & $37.95^{\mathrm{c}} \pm 0.05$ & $25.50^{\mathrm{d}} \pm 0.70$ \\
\hline 4 & $\boldsymbol{\alpha}$-Cellulose & $37.00^{\mathrm{e}} \pm 0.58$ & $34.00^{\mathrm{f}} \pm 0.28$ \\
\hline 5 & Hemicellulose & $29.00^{\mathrm{e}} \pm 0.76$ & $46.00^{\mathrm{f}} \pm 0.01$ \\
\hline 6 & Lignin & $27.00^{ \pm} \pm 0.28$ & $28.00^{\mathrm{h}} \pm 0.50$ \\
\hline
\end{tabular}

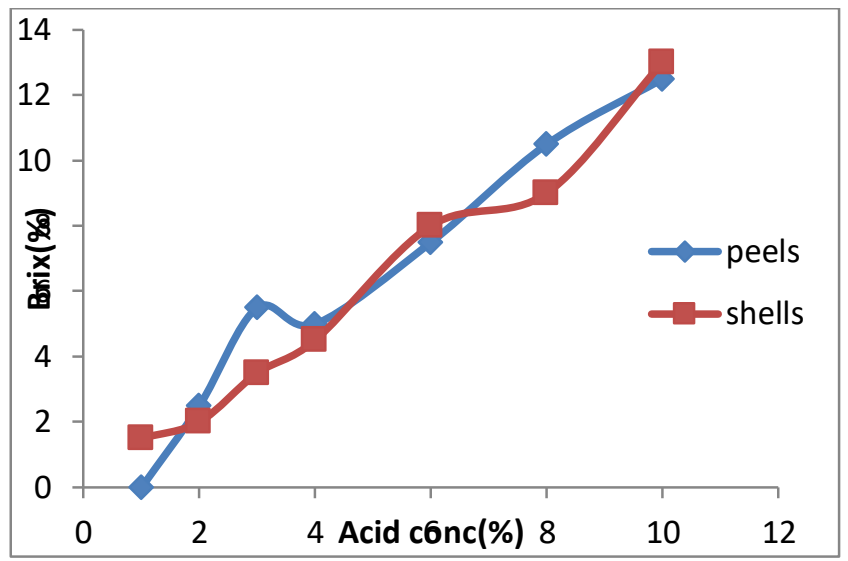

Figure 1: Effect of Acid Concentration against Brix at 30min, $80{ }^{\circ} \mathrm{C}$

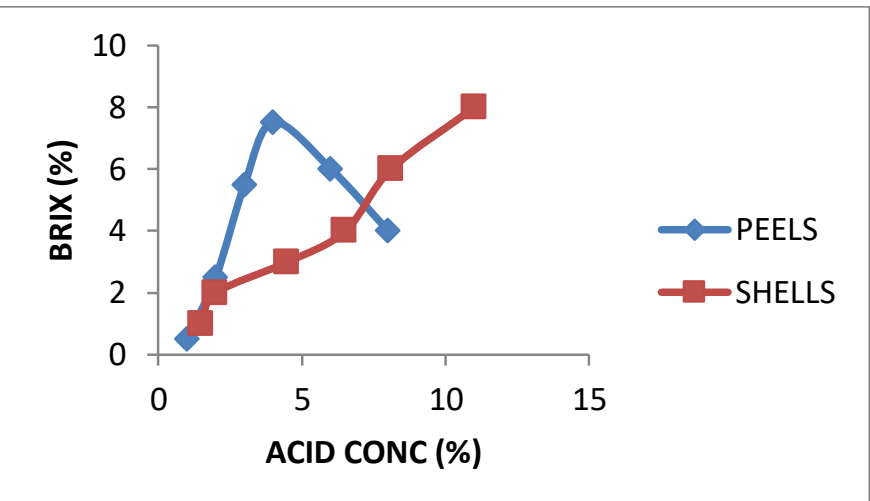

Figure 2: Effect of Acid Concentration against Brix at 60 minutes, $100{ }^{\circ} \mathrm{C}$

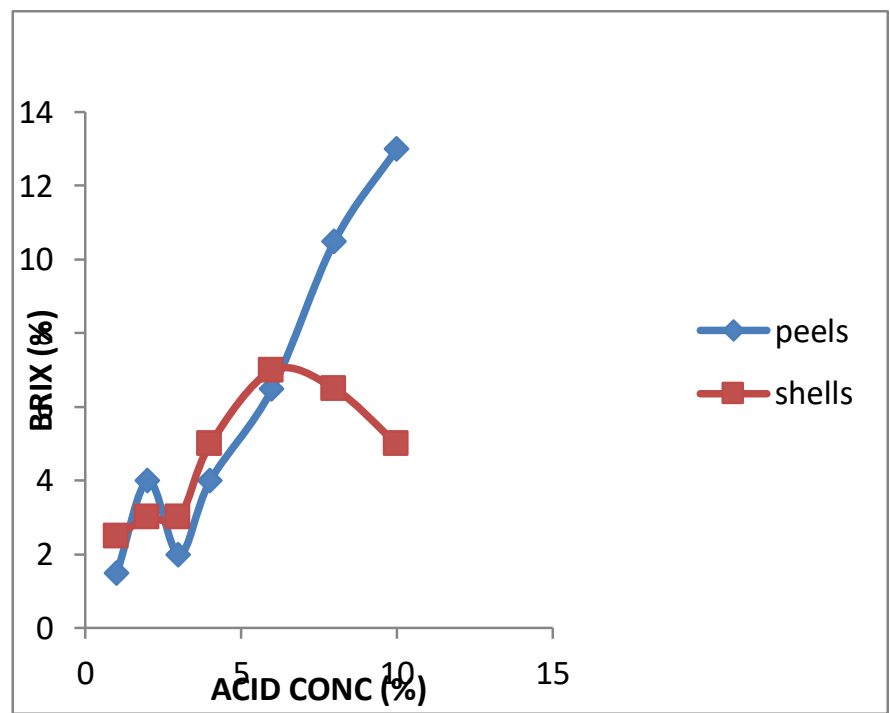

Figure 3: Effect of Acid Concentration against Brix at 90 $\min , 120{ }^{\circ} \mathrm{C}$ 


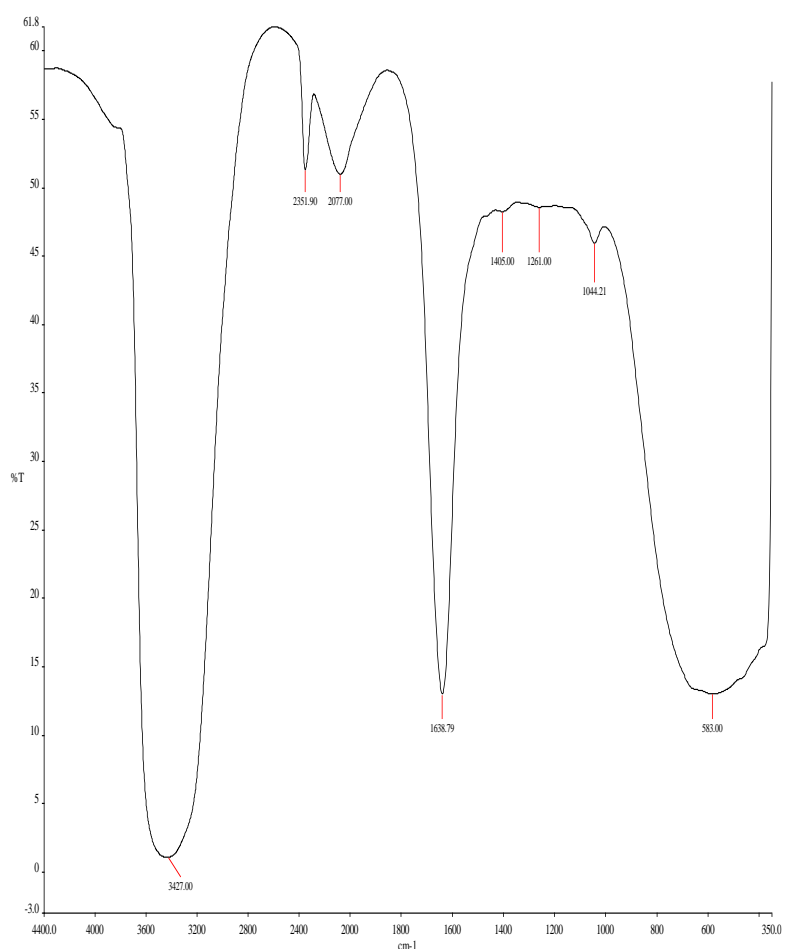

Figure 4: FTIR Spectrum for Derived Bio Ethanol Groundnut Peels

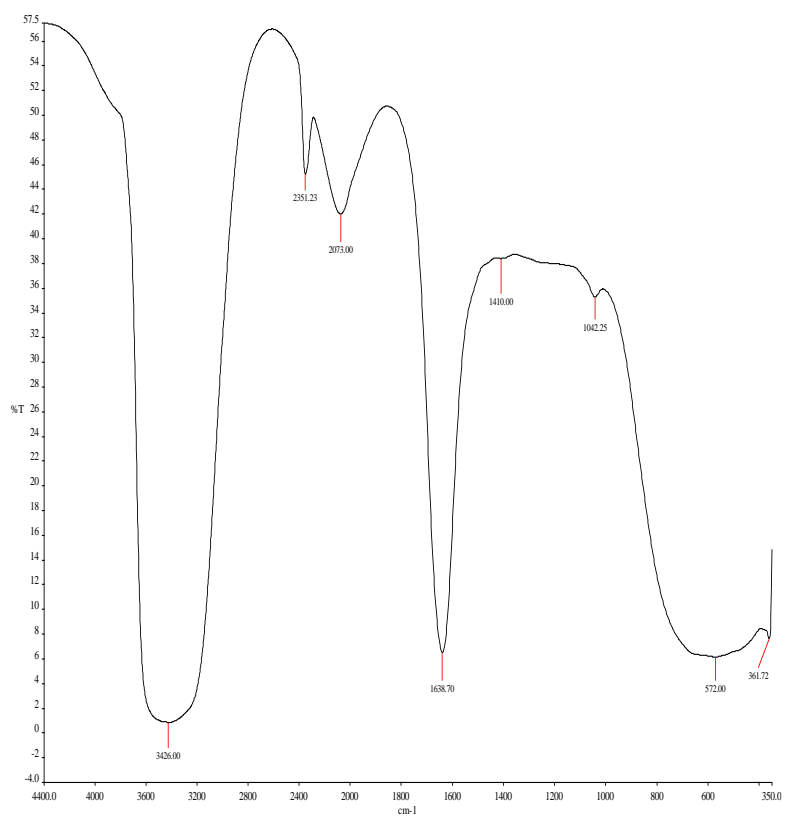

Figure 5: FTIR Spectrum for Derived Bio Ethanol Groundnut Shells

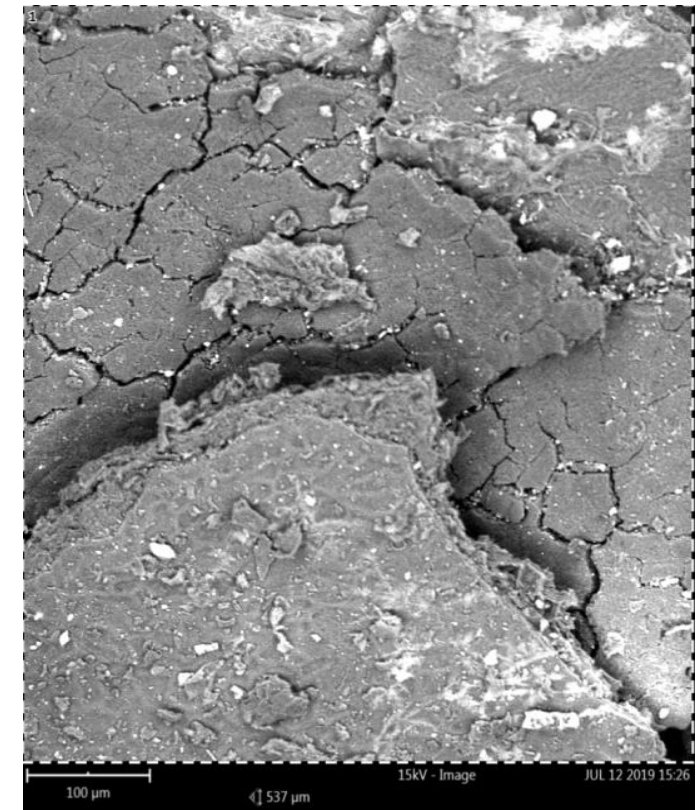

Plate 2a: Pre-hydrolyzed groundnut peels

Scanning Electron Microscopy: Plates (2a, 2b) and (3a, 3b) show the SEM micrographs of the Pre and Post hydrolyzed groundnut biomass. SEM analysis was carried out on Pre and Post hydrolysed groundnut shells. Plate $2 \mathrm{a}$ and $3 \mathrm{a}$ show smooth surface with a compacts structure that was well organized while plate $2 \mathrm{~b}$ and $3 \mathrm{~b}$ show a ruptured surface which signified effective hydrolysis that opened up the pores space on the biomass

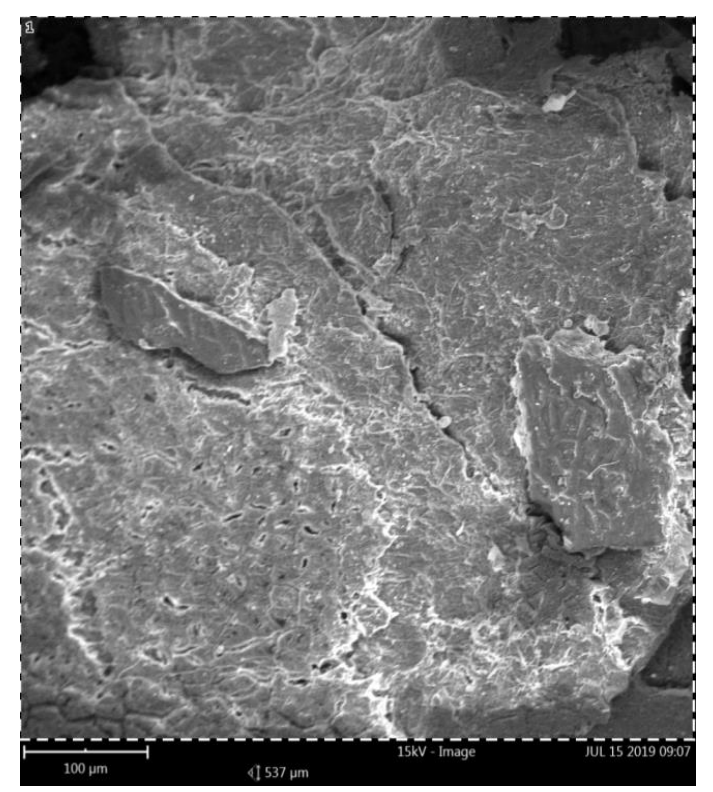

Plate 2b: Post- hydrolysed groundnut shells 


\section{International Journal of Engineering Applied Sciences and Technology, 2020 \\ Vol. 4, Issue 11, ISSN No. 2455-2143, Pages 38-44 \\ Published Online March 2020 in IJEAST (http://www.ijeast.com)}

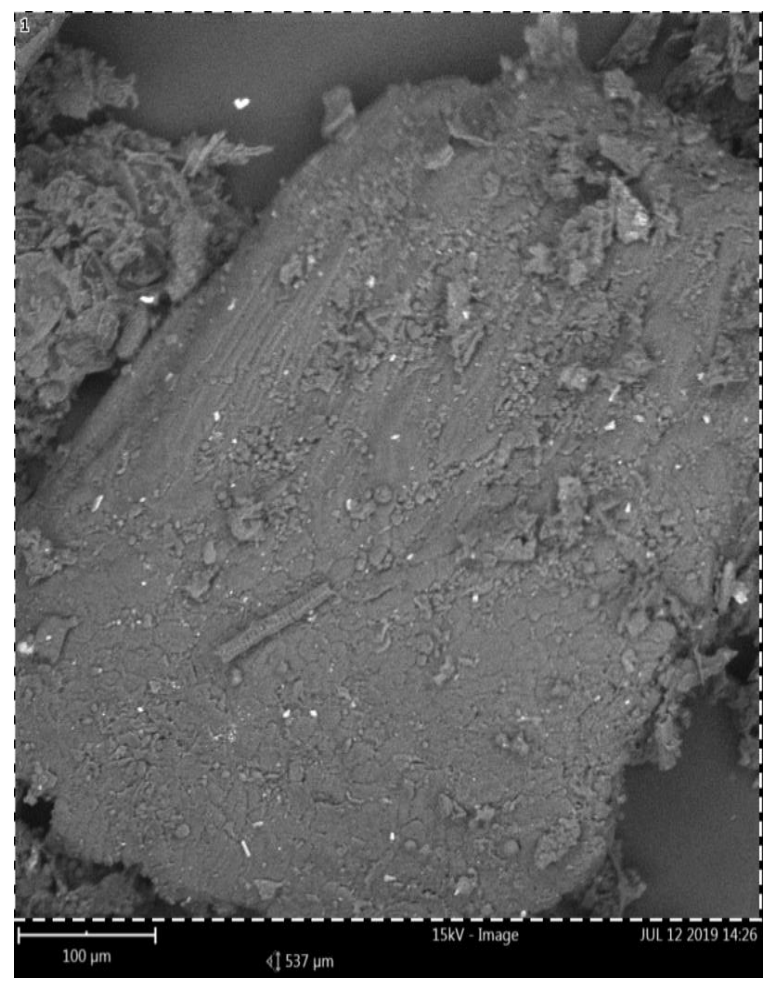

Plate 3a: Pre hydrolysed Groundnut shells

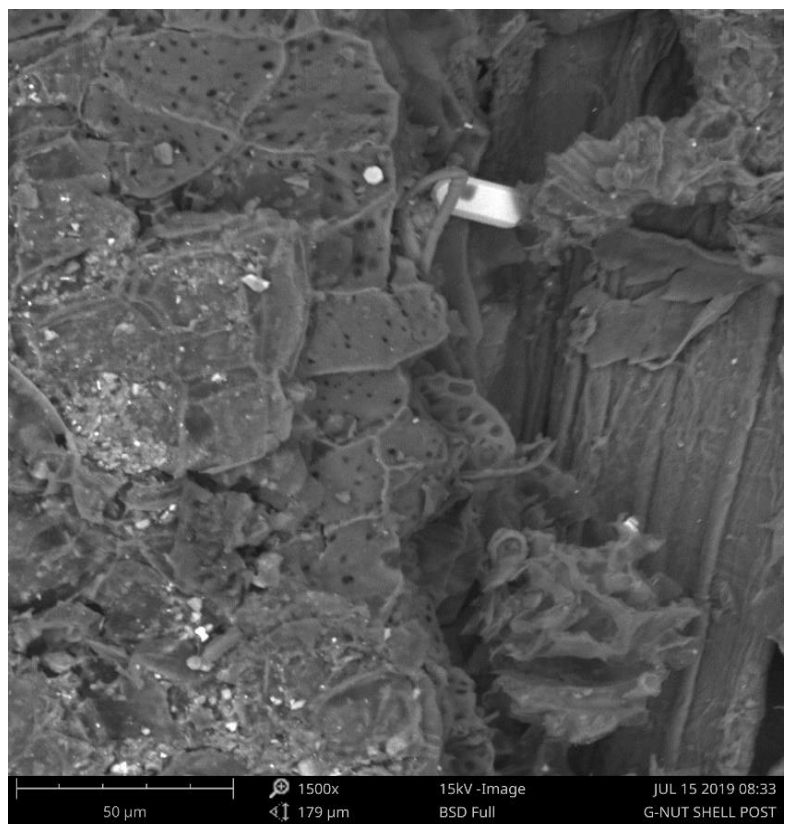

Plate 3b: Post hydrolysed Groundnut shell

\section{CONCLUSION}

The moisture content of the biomass was low which implies no need for drying pretreatment in production of bio fuel. The ash of the groundnut peels and shells can be used for soil remediation.

The optimum acid concentration for the release of sugar for groundnut peel and shell were $4 \% \mathrm{w} / \mathrm{v}, 6 \% \mathrm{w} / \mathrm{v}$ of acid respectively. Also, reaction time was $\left(60 \mathrm{~min}, 100{ }^{\circ} \mathrm{C}\right.$, and $90 \mathrm{~min}, 120^{\circ} \mathrm{C}$ ) for peels and shells.

Groundnut peels and shells are promising feedstock as a result of high amount of cellulose, lignin, and hemicellulose. The yeast used was Saccharomyces cerevisiae for the fermentation which took 5 days to ferment.

Bioethanol from groundnut peels and shells can be used as an alternative to synthetic ethanol and can be used as source of fuel and preservatives in confectionaries.

\section{REFERENCES}

[1]. Juliet, B., Vasilije, M. and Philiph, L. (2016) 'Biomass resources and biofuels potential for the production of transport fuels in Nigeria', Renewable and Sustainable Review, Vol. 63, pp.172-192

[2]. Akorede, M.F., Ibrahim, O., Amuda, S.A., Otuoze, A.O. and Olufeagba, B.J. (2017) 'Current status and outlook of renewable energy development in Nigeria', Nigerian Journal of Technology (NIJOTECH), Vol. 36, No. 1, pp.196-212

[3].Giwa, A., Alabi, A., Yusuf, A. and Olukan, T. (2017) 'A comprehensive review on biomass and solar energy for sustainable energy generation in Nigeria', Renewable and Sustainable Energy Reviews, Vol. 69, pp.620-641.

[4]. FAOSTAT (2013) Food and Agriculture Organization of theUnitedNations, Rome[online]www.fao.org/docrep/0 18/i3107e/i3107e.PDF (accessed 20 October 2018) .A.O. (2018).

[5]. Food and Agriculture organization of the united nation .(2018) The future of food and agriculture-Alternative pathways to 2050.Rome.p 224. CC.BY-NC-SA 3.0 IGO.

[6]. Naik, V., Goud, P. K., Rout, B., and Dalai, A.K. (2010) .Production of first and second generation biofuels, A comprehensive review. Renewable and Sustainable Energy Reviews, vol. 14, pp. 578-597.

[7]. Lavanya, D., Kulkarni, P.K., Dixi,t M., Raavi, P.,K. and Krishna, L.N.V.(2011). Sources of cellulose and their applications- A review. International Journal of Drug Formulation and Research; 2(6): pp 19-38.

[8]. Abbakar M, Elsheikh M, (Investigation of alpha-cellulose local sources for the Production of Nitrocellulose). International Journal of Sciences: Basic and Applied Research, 2015; 19(2): 35-50.

[9]. Costa, A., Fonesca, A.F., Pereira, F.V.,, And Druzian J.I.(2015). Extraction and Characterization of Cellulose Nanocrystals from Corn Stover Larissa. Cellulose Chemical Technology; 49(2):pp 127-133. 


\section{International Journal of Engineering Applied Sciences and Technology, 2020 \\ Vol. 4, Issue 11, ISSN No. 2455-2143, Pages 38-44 \\ Published Online March 2020 in IJEAST (http://www.ijeast.com)}

Economics Division, Forestry Department: Kingston, Jamaica, 2004

[10]. Herrera, S. (2004) "Industrial biotechnology- a chance at redemption", Nature Biotechnology, 22, pp 671-675

[11]. Lynd, L.R., Van Zyl, W.H., McBride, J.E. and Laser, M.. (2005). Consolidated bioprocessing of cellulosic biomass: an update. Current Opinon in Biotechnology. 16 , pp 577-583.

[12]. Chandel, A.K., Singh, O.V., Chandrasekhar, G., Rao, L.V. and Narasu, M.L. (2010). Key drivers influencing the commercialization of ethanol-based biorefineries, Journal of Commercial Biotechnology. 16.3,pp 239-257.

[13]. Cuellar, M.C., and Straathof, A.J.J. (2014). Biochemical Conversion, in Biomass as a Sustainable Energy Source for the Future: Fundam Processes. John Wiley \& Sons, Inc, Hoboken, NJ

[14]. Ogunsuyi, H.O., and Badiru, A. (2016). Production and Chemical evaluation of Bioethanol derived From White Cocoyam (Colocasia Antiquorium) and Sweet Potatoes (Ipomoea Batatas) cultivars. International Journal of Advanced Scientific Research and Management. Vol. 1 Issue 7.

[15]. Josly, (1970). Association of Official Analytical Chemists (1990). Official Methods of Analysis. 15th Ed. Washington D.C.: Association of Official Analytical Chemists. Vol. 4 and 5.

[16]. Technical Association of Pulp and paper Industry (TAPPI). (1998) Acid-insoluble lignin in wood and pulp T222OM-98. Technol. 83, 37-46

[17].Appleton,W.(1951) The institute of paper chemistry34,the nature of polysaccharide hydrolysis in black gumwood reacted with water at 160 pp 3.97 102

[18].Wise L. (1962). Garcia, Consuelo Tappi 34(4).

[19]. Kurschner K., and Hoffer A. (1931). A new quantitative cellulose determination, Chem. Zeit. 55. p 1811

[20]. Miguel-Angel, P., Francisco, M.A.,Quetzalcoatl, H.E., and Alberto-Jesus, P.M(2018). Peanut Shell for Energy: Properties and Its Potential to Respect the Environment. Sustainability. 10, p 3254.

[21]. Annika, D. G., Tejas, S., Vineetha, N., and Pratima, P. (2017). Extraction of Cellulose and Biofuel Production from Groundnut Shells and Its Application To Increase Crop Yield. World Journal of Pharmacy and Pharmaceutical Sciences .Vol. 6, Issue 6, pp 1820-1831

[22].Kutshik, J.R., Usman, A.M., and Ali-Dunkrah, U. (2016). Comparative study of protein enrichment of lignocellulose wastes using baker's yeast (Saccharomyces cerevisiae) for animal feeds. IOSR J. Biotechnol. Biochem. 2 (7), pp 73-77 